\title{
The Vascular Vegetation Populating the Flora in Building Materials of Historic Monuments Cities of the West Central Region of Morocco
}

\author{
Bouamar Baghdad', A. Taleb1', A. Carlo Iñigo Iñigo², H. El Hadi'3 , M. Dalimi' \\ ${ }^{1}$ Department Natural Resources and Environment, Agronomic and Veterinary Institute-Hassan II, \\ Rabat, Morocco \\ ${ }^{2}$ Instituto de Recursos Naturales y Agrobiología de Salamanca (IRNASA), Consejo Superior de Investigaciones \\ Científicas (CSIC), Salamanca, Spain \\ ${ }^{3}$ Laboratory of Applied Geology, Geomatics and Environment, Faculty of Science of Ben M'Sik, Hassan II \\ University, Casablanca, Morocco \\ ${ }^{4}$ Department of Chemistry, Faculty of Science and Technology, University Hassan II, Mohammedia, Morocco \\ Email: bouamar.baghdad@gmail.com
}

Received 12 May 2014; revised 12 June 2014; accepted 18 June 2014

Copyright (C) 2014 by authors and Scientific Research Publishing Inc. This work is licensed under the Creative Commons Attribution International License (CC BY). http://creativecommons.org/licenses/by/4.0/

(c) () Open Access

\section{Abstract}

In the concern of the preservation of the main historic monuments of the cities of Rabat and Sale (Morocco), a botanical study was conducted in 2009. The prospecting of these monuments allowed raising an inventory of the flora populating their building materials, and it has proved that this flora is rich and diversified. Indeed, it consists of 171 adventitious species distributed in 46 botanical families. The most represented families are Asteraceae, Poaceae, Fabaceae, Caryophyllaceae, Geraniaceae, Brassicaceae and Lamiaceae. They supply, to them only $49.7 \%$ of the specific size. The annual therophytes and the dicotyledon are dominant with respectively $66.7 \%$ and $84.7 \%$ of the specific size. Nevertheless, the presence of more than 20 species of trees and perennials constitutes a serious danger for bulwarks walls, especially by the phenomenon of fissuring by the action of the huge roots of these vegetables. These vegetables fitting into are placed on joints or cracks fissures have a chemical action on stones by acids that they release, and also a mechanical action by the growth of roots inside cracks fissures. They remain one of these are one of the important biological factors of the degradation of historic monuments. It is to note that the bulwarks walls of the site of Chella (Roman ruins) present more floral diversity than the other canvassed monuments ( 91 species) that are $53 \%$ of the total size. 


\section{Keywords}

\section{Degradation, Historic Monuments, Building Materials, Flora, Morocco}

\section{Introduction}

Building materials, all around the world, are exposed to several factors of degradation and change alteration: the climate, the biological human beings and the weather. The action of these factors is modulated according to the questioned type of the source rock. In the case of historic monuments, a number of important specific factors come to add bounded to the anthropological action: mode of construction (presence of mortars and cements), composition of the atmosphere, the rains, etc. [1] [2].

Although, it is often difficult to separate the role of the big factors of change alteration, the biological action remains is specific compared with that more general of the climate; it corresponds to the fact that the specialists of historic monuments mention the biodegradation of stones and building materials with regard to the physicochemical change alteration depending on the only climate [1] [3] [4].

The present study aims to inventory and to characterize the flora populating of the building materials of the main historic monuments of the cities of the west central region of Morocco to clearly take out concrete proposals of arrangement at the levels of the preservation conservation, the restoration and the rehabilitation.

\section{Material and Methods}

\subsection{Study Areas}

In this paper, a interest focuses on the stone flora weathering of some old and historical Rabat and Salé cities (Figure 1) in Morocco.

These monuments are all constructed by the calcarenitic stones. It is characterized by variable and high porosity $(18 \%-47 \%)$ and thus an elevated permeability, and generally bad geotechnical quality [5]. Its chemical composition is very rich in calcium carbonates and its rough surface allows a high receptivity to the atmospheric gaseous pollutants and to hydrous marine sprays charged with various salts.

\section{Climatology}

Located along the Atlantic Ocean, with a Mediterranean climate character, the studied region has a mild, temperate climate, shifting from cool in winter to warm days in the summer months. Characterized by the alternation of a wet season from October to April which the average temperatures reaches $14^{\circ} \mathrm{C}$ and a hot dry season from

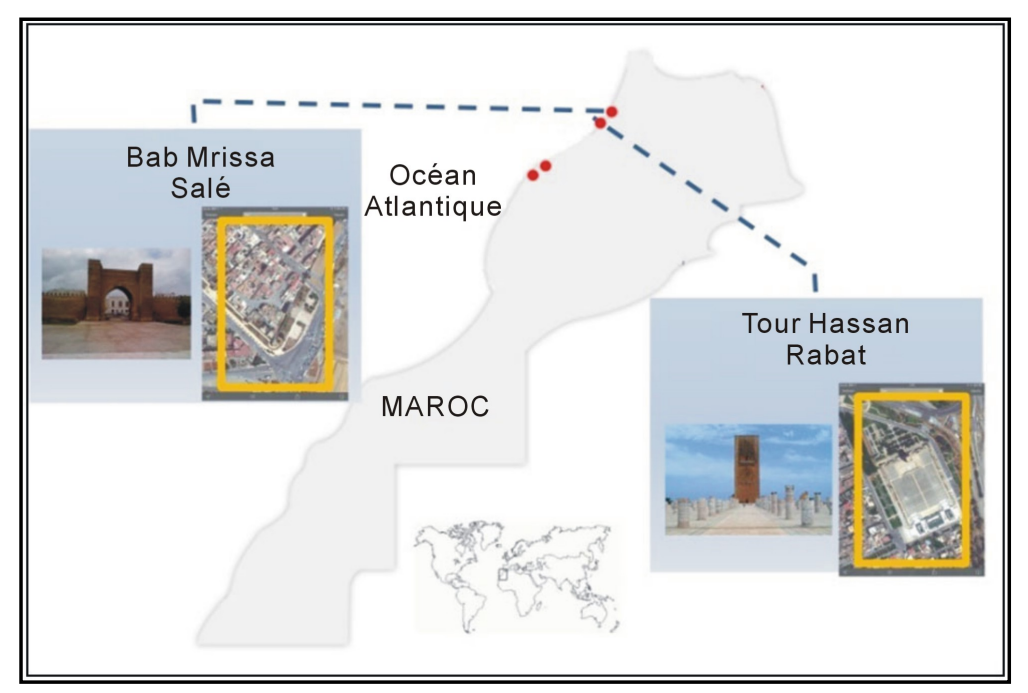

Figure 1. Geographical situation of the most important historical sites of Rabat and Sale cities, Morroco. 
May to September which the average temperatures reaches $24^{\circ} \mathrm{C}$, the mean air temperature varies between $16.3^{\circ} \mathrm{C}$ (with mean minimum of $10.0^{\circ} \mathrm{C}$ and mean maximum of $23.8^{\circ} \mathrm{C}$ ) at Rabat and Sale Cities.

The opening of the region on the Atlantic Ocean earned him abundant precipitations that are around an average of $450 \mathrm{~mm}$ per year in recent 30 years. Pluviometry is concentrated between October 15 and April 15 at $90 \%$.

\subsection{Sampling}

Floristic surveys were conducted using a systematic sampling in the most important historical sites of Rabat and Sale cities (Figure 1), that is to say, the most important in terms of tourism, the most touristic and infested by plants and according to their states of degradation. Three locations walls (Summit or Top, Interior and Exterior) were explored and all plants present were collected systematically. A series of photos were taken, representing different states infestations walls.

\subsection{Species Identification}

The determination of plant species was realized at the department of plant ecology, Institute of Agronomy and Veterinary-Hassan II, with the following catalogue flora: The illustrated flora of weeds in crops of Gharb [6] [7], the new flora of Algeria and southern desert regions [8]. Identifications checking were made according to the catalogue of plants of Morocco [9] and synonymous index of taxa present in cultivated and artificial environments of Morocco [10].

\section{Results and Discussion}

\subsection{Systematic Aspect}

The flora so listed consists of 171 species belonging to 46 botanical families among 4 monocotyledons and 42 dicotyledons. According to their relative contributions, seven of them dominate very clearly the flora of these historic monuments in genres and in species namely: Asteraceae (27 species), Poaceae (16 species), Fabaceae (10 species), Caryophyllaceae (9 species), Geraniaceae (8 species), Brassicaceae (8 species), Lamiaceae (7 species). These families add up to them only 85 species, that is $49.7 \%$ of the specific size.

The importance of these families can be explained by their high productivity of seeds, of the big longevity of their seeds, the scattering of seeds by the wind and birds, and the phenology perfectly adapted to the nature of the building materials of historic monuments. From systematic point of view, dicotyledons dominate with $84.7 \%$ of the total size against $15.3 \%$ of the monocotyledon species.

Current research realized in 4 Moroccan historical cities to study the effect of flora on these monuments, with a view to expanding this work to study the overall effect of these organisms on heritage masonry [5].

The main results indicate, the total number of vascular plants growing spontaneously on walls included 129 species with 33 families and 74 genera (81 species, 13 subspecies and 7 varieties). Eighty species were Dicotyledones with one monocotyledon species and while Dicotyledones were the prevalent group with $98.76 \%$ of all species. The following families were represented by the largest number of species: Asteraceae (18 species, 22.22\%), Poaceae (8 species, 9.87\%), Lamiaceae (5 species, 6.17\%), Brassicaceae (5 species, 6.17\%), Polygonaceae (4 species, $4.93 \%$ ) and Scrophulariaceae (4 species, $4.93 \%$ )

These results show that different species inventoried in the two studies are comparble with differences in the spatial distribution.

\subsection{Biological Aspect}

According to the Raunkiaer classification (1905) [11], which bases on the position of the permanent buds during the period of the vegetative rest with regard to the surface of the ground, 171 species belong to 4 biological types (Table 1). This flora is dominated by the (annual) therophytes constituted by 114 species either (66.9\% of the specific size), followed by geophytes with 22 species either (12.4\% of the specific size), which besides the multiplication by sexual way, they multiply easily by organs (Convolvolus arvensis L., Convolvolus althaeoides L.), others they mainly multiply by vegetative way (Cyperus rotundus L., Cynodon dactylon (L.) Pers., and Oxalis pes-caprae $\mathrm{L}$.).

The tree-dwelling vegetation is represented by several species among which karoo, Acacia karoo, Acacia 
Table 1. Distribution of the botanical species by Rabat and Sale monuments.

\begin{tabular}{ccc}
\hline & Monuments & Numbers of species \\
\hline Bab Laalou & 18 \\
Chella & 91 \\
Muraille Al Mohad & 12 \\
Muraille BAab El Had & 16 \\
Muraille Bab Sewiqa & 9 \\
Muraille Hassan & 57 \\
Oudaya & 54 \\
Tour Hassan & 15 \\
\hline Bab Fes & 15 \\
Bab Sebta & 7 \\
Borj Sidi Bachir & 13 \\
Carrière Bouknadel & 24 \\
Carrière El Gorna & 29 \\
Maderssa Marinia & 4 \\
Muraille Bab Mressi & 24 \\
Muraille Chaafa & 12 \\
Muraille Sebta & 26 \\
Qasbat Guenawa & 27 \\
Zawyate Ennossak & 20 \\
\hline
\end{tabular}

cyanophylla, Olea europea, Celtis australis, Rubus ulmifolius, Ficus elastica, Ficus carica, Prunus amygdalus, Nicotiana glauca et Jasminum fruticans (Figure 2). These species have fleshy fruits and are often spread by birds.

\section{Action of Plants on Monuments}

The plants which grow on buildings indicate generally the presence of humidity in the joints of materials. After the sowing (presence of seeds), the parameters of the environment favoring the growth of these vegetables are the light, the oxygen and the carbon dioxide. Mineral salts result from rocky materials. Generally, roots stress the deterioration of masonries monuments. The presence of plants on buildings and stone elements testifies especially of a lack of maintenance.

In the case of carbonates rocks, the phenomena of dissolution by roots and recrystallising of calcite inside the cortical cells were established well by [12]. This leads to the reconstruction of real structures of calcitized rhizomorphes forming ribbons from 1 to $2 \mathrm{~mm}$ wide; calcitized cells of a size of $100 \mu \mathrm{m}$ belong as well to the skin, the cortical parenchyma and the endoderm. The most dangerous category is phanerophytes (trees) which, by their volume of roots explode walls and create deep cracks.

Obviously for historic monuments, the presence of mosses and vegetables already supposes certain degree of alteration which it is necessary to remedy (Figure 3).

\section{Action of Seaweeds and Lichens}

Seaweeds and lichens are pioneering vegetables and are well represented in the colonization of the rocks; acid crystalline rocks or carbonated rocks. Facings are sometimes locally covered by seaweeds and bodies been originated to seaweeds; this observation is always connected to the presence of the humidity. The existence of this vegetation is mainly visible in the bases of facades or in the zones in touch with the ground, as a result of the ascents of water by capillarity. The presence of seaweeds on a facing is significant to quickly localize the humidity on an element.

Certain damage decays are attributable to the moistening and the frequent drying of rocks. In the locations where develop seaweeds, stones have a humidity often superior to the water content in equilibrium, because the vegetation, for its growth, needs some water of the wall. 


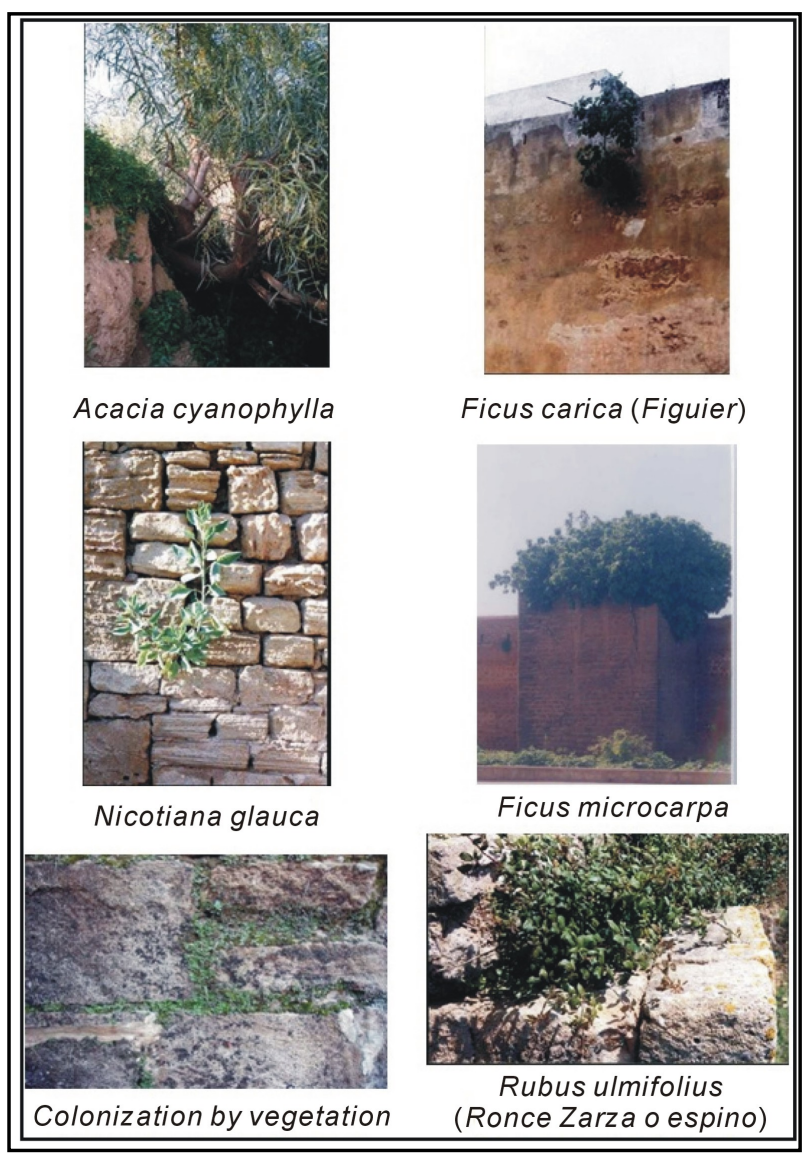

Figure 2. Some species growing on the walls.

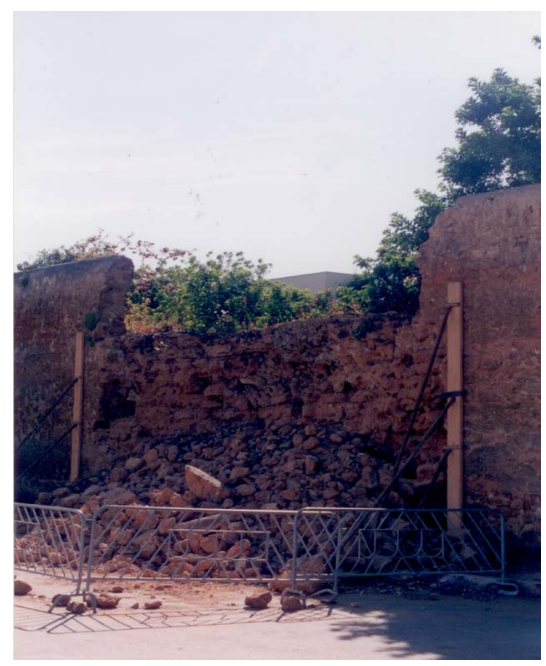

Figure 3. Thrashing has the effect of tree roots (Wall of Rabat).

\section{Conclusions}

From botanic studies conducted, it can be concluded that:

1) The most present families in the monuments of the west-central Morocco are: Asteraceae, Poaceae, Fabaceae, Caryophyllaceae, Geraniaceae, Brassicaceae and Lamiaceae; 
2) The vegetal species, which are able to grow in the construction materials of the main historical monuments of Rabat and Salé (Morocco), are abundant and diverse. The deterioration may be physical, by action of roots, or chemical by substances secreted by the metabolism to construction materials;

3) The vascular plants that produce more damage to monuments by physical action of their roots are the arborescent;

4) The dicotyledonous plants are more frequent than monocotyledonous.

\section{Acknowledgements}

The authors thank the facilities in the various canvassed sites by Ministry of the Higher Education and the Training of Executives, the Heritage Department and conservatives of the various canvassed sites.

\section{References}

[1] Iñigo, A.C., Rives, V. and Vicente, M.A. (2000) Reproducción en Cámara Climática de las Formas de Alteración más Frecuentes Detectadas en Materiales Graníticos, en Clima de Tendencia Continental. Materiales de Construcción, 50, 57-60. http://dx.doi.org/10.3989/mc.2000.v50.i257.418

[2] Iñigo, A.C., García-Talegón, J., Trujillano, R., Molina, E. and Rives, V. (2003) Evolution and Decay Processes in the Villamayor and Zamora Sandstone. In: Pérez-Rodríguez, J.L., Ed., Applied Study of Cultural Heritage and Clays, 47-57.

[3] O’Brien, P.F., Bell, E., Pavia-Santamaria, S., Boyland, P. and Cooper, T.P. (1995) Role of Mortars in the Decay of Granite. Science of the Total Environment, 167, 103-110. http://dx.doi.org/10.1016/0048-9697(95)04573-J

[4] Robert, M., Galsomies, L., Tessier, D., Jaunet, A.M., Iñigo, A.C. and Elsass, F.(2003) Degradation of Historical Monuments. Role of the Different Mechanisms, Processes and Microsystems. In: Pérez-Rodríguez, J.L., Ed., Applied Study of Cultural Heritage and Clays, 17-28.

[5] Dalimi, M., Zakarya, D., Baghdad, B., Taleb, A. and Iñigo, A.C.I. (2012) Vegetations as Biodeterioration Agents on Archaeological Stones: Comparative Study of Plants Species Found on the Walls of Some Moroccan Historical Monuments. Journal of Research in agriculture, 2, 001-005.

[6] Taleb, A. and Maillet, J. (1994) Mauvaises Herbes des céréales de la Chaouia (Maroc) I: Aspect Floristique. Weed Research, 34, 345-352. http://dx.doi.org/10.1111/j.1365-3180.1994.tb02003.x

[7] Taleb, A. (1995) Flore illustrée des Adventices des Cultures du Gharb. Thèse Doctorat ès-Sciences Agronomiques, Institut Agronomique et Vétérinaire Hassan II, 2, 369.

[8] Quezel, P. and Santa, S. (1962, 1963) Nouvelle Flore d’Algérie et des Régions Désertiques Méridionales. 2 Tomes, Editions CNRS, Paris, 1170.

[9] Jahandiez, E. and Maire R. (1931, 1932, 1934) Catalogue des Plantes du Maroc. 3 Tomes, Editions Lechevalier, Paris, 913.

[10] Boulet, C., Tanji, A. and Taleb, A. (1989) Index Synonymique des Taxons Présents Dans les Milieux Cultives ou Artificialises du Maroc Occidental et Central. Actes Inst. Agron. \& Veteri., 9, 65-98.

[11] Raunkiaer, C. (1905) Types Biologiques pour la Geographie Botanique. (Kgl. Danskevidenskabeernes Sclskabs Forhandt, 5, 347-437) Bull. Acad. R. Sc. Danemark, 347-437 ;

[12] Jaillard, B. (1987) Les Structures Rhizomorphes Calcaires: Modèle de Réorganisation des Minéraux du sol Par les Racines. Pub. INRA Montpellier, France, 219. 